The efficacy of the second-line chemotherapy commonly used in both relapsed ovarian cancer patients and those with primary treatment failure remains unsatisfactory. This therapy has a small effect on survival, whereas associated toxicity may diminish the patient's quality of life.

Hormonal factors play a role in ovarian tumorigenesis, and inhibition of the stimulating effects of estrogens may exert a clinical benefit. The role of hormonal therapy as a palliative therapeutic alternative for ovarian cancer remains undetermined. This modality may result in long-term stabilization of disease in individual patients and less frequently in tumor remission.

In this article the role of hormonal factors and recent literature of various forms of hormonal therapy for ovarian cancer are presented.

Key words: ovarian cancer, endocrine therapy, estrogens, aromatase inhibitors.

\section{The role of hormonal factors and endocrine therapy in ovarian cancer}

\author{
Krystyna Serkies, Marcin Sinacki, Jacek Jassem
}

Oncology and Radiotherapy Department, Medical University of Gdańsk, Poland

\section{Introduction}

Ovarian cancer is most frequently diagnosed at an advanced stage, is recurrent and is generally of poor prognosis. This primary is the fourth most common cause of female cancer death in Poland [1].

The efficacy of the second- as well as following lines of chemotherapy (CHT) used both in relapsed ovarian cancer patients and those with primary treatment failure remains unsatisfactory. Moreover, $\mathrm{CHT}$ associated toxicity may diminish the patient's quality of life. This treatment is administered until cancer progression or tolerance worsening occurs, and disease stabilization is regarded as a clinical benefit. Overall, an approximately 20-30\% objective response rate, mainly with partial cancer regression, is observed with the second-line $\mathrm{CHT}$.

In a randomized phase III trial of pegylated liposomal doxorubicin (PLD) and topotecan the response rate of $19.7 \%$ and $17 \%$, median overall survival (OS) of 62.7 and 59.7 weeks and 3 -year OS of $20.2 \%$ and $13.2 \%$ in a group of unselected recurrent or refractory ovarian cancer patients, respectively, were reported [2, 3]. In other studies of retreatment with a platinum compound and paclitaxel median progression-free survival (PFS) was 13 months [4] and 8.6 months [5], and the response rate was 30.9\% [4] and 47.2\% [5] among patients with the best prognosis, i.e. with relapsed platinum-sensitive ovarian cancer (patients who relapse 6 months or more after initial platinum/paclitaxel CHT).

Moreover, the response rate of $6.1 \%$ and $8.3 \%$, median PFS of 3.6 and 3.1 months, and median OS of 12.7 and 13.5 months were obtained with gemcitabine and PLD, respectively, in patients with platinum-resistant ovarian cancer (patients whose disease recurs in less than 6 months after platinum-based therapy used in the primary setting) [6].

In this group of patients the respective 3 -year OS was $13.8 \%$ and $9.5 \%$ with PLD and topotecan [2]. The duration of response obtained with consecutive lines of CHT was shorter, and the chance of response was decreased.

Chemotherapy associated toxicity, mostly hematological, including severe (grade 3 and 4), is present in approximately one third of cases, and may significantly diminish the patient's quality of life [4-6].

Unsatisfactory efficacy of $\mathrm{CHT}$, and sometimes lack of other regimens to administer, encourage the search for a palliative therapeutic alternative for ovarian cancer.

In this article the role of hormonal factors and recent literature on various forms of hormonal therapy for ovarian cancer are presented.

\section{The role of hormonal factors in ovarian cancer}

There are some epidemiological, experimental and clinical data that suggest an important role of hormonal factors in ovarian carcinogenesis [7, 8]. Ovarian cancer risk is increased in nulliparity, and decreased risk of ovarian cancer is associated with younger age at pregnancy and first birth, the use of oral contraceptives and/or breast-feeding. Ovarian cancer may develop in 
women previously treated for breast or corpus uterine carcinomas.

Despite the inconsistent data concerning a possible association between hormonal replacement therapy (HRT) and ovarian cancer risk, HRT, especially when it exceeds 10 years, was associated with 1.45-2.2 increase in relative risk of this malignancy [7, 9]. The risk could increase with the increased cumulative estrogen dose over time. Meanwhile, concomitant administration of progestin and estrogen may counteract the risk associated with estrogen use.

Studies in vitro and in animal models support data concerning estrogen's role in promoting epithelial ovarian tumor growth. Estrogen exerts its stimulatory effect mainly through the estrogen receptor (ER), which is present in $38-60 \%$ of epithelial ovarian cancer tumors $[7,10]$. There are two types of ER, ER $\alpha$ and ER $\beta$ (with opposite antiproliferative vs. pro-proliferative effects, respectively), encoded by different genes.

Low-level ER expression is associated with early stage and higher tumor differentiation. Endometrioid and serous tumors express higher levels of ER as compared to other histological types. Prolonged treatment with tamoxifen enables reduction of the expression of ER $\beta$ in ovarian cancer cells [11].

The $E R \alpha$ form predominates in normal ovaries, the $\beta$ form in normal ovaries and benign tumors. The exact role of particular forms of ER (and its variants), as well as the patterns of ER and progesterone receptor (PR) in ovarian tumorigenesis, the role of the response to endocrine therapy and the prognostic significance, continue to be under investigation $[12,13]$. According to some authors, tumors of high PR expression and without ER have the best prognosis [13].

The mechanism of estrogen's mitogenic effect, and ER regulation of expression of several proteins in ovarian cancer, is not fully determined. The growth-inducing effect of estrogens is mediated mainly through nuclear ER $\alpha$. The binding of estrogen to ER can increase or inhibit the transcription of many estrogen-responsive genes and their products (for example PR, cathepsin D, c-myc, bcl-2), which influence cell proliferation, tumor invasion and tumor responsiveness to endocrine therapy [7]. A mechanism of estrogen tumorigenesis not mediated by ER has also been suggested; both estrogen and its metabolites can directly damage DNA [14, 15]. Molecular factors that predict response to hormonal therapy and could help to identify patients who benefit the most from such treatment have been under investigation $[16,17]$.

\section{Hormonal therapy in ovarian cancer}

Selected phase II studies of hormonal therapy for ovarian cancer are shown in Table 1.

\section{Selective estrogen receptor modifiers (SERMs)}

The main mechanism of selective ER modulators function is their anti-estrogen effect through competitive combination with ER in ovarian cancer cells with a consequence of inhibition of estrogen/ER complex translocation into the nucleus. Tamoxifen, the main agent among SERMs, may also inhibit the activity of some polypeptide growth factors and conversion of estrone to estradiol. Novel SERMs include raloxifene, which has a smaller agonistic effect compared to tamoxifen, and the pure (without any agonistic activity) ER antagonist fulvestrant.

Prolonged tamoxifen treatment stimulates ovarian steroidogenesis and thus increases the incidence of benign ovarian cysts in breast cancer patients, and in pre- or perimenopausal women with ovarian cancer [18]. In in vitro studies, however, tamoxifen inhibits ovarian cancer cell growth [19].

In clinical series ovarian cancer patients were administered tamoxifen at a daily dose of 20 to $40 \mathrm{mg}$ (sometimes up to $80 \mathrm{mg}$ ) both as a single agent or concurrently with CHT. These studies mostly included heavily pretreated or platinumresistant patients. The efficacy of concomitant use of tamoxifen and CHT was evaluated in phase II trials; however, owing to the limited accrual their results were inconsistent [20, 21]. According to some authors tamoxifen in advanced ovarian cancer has not been adequately evaluated in well-designed trials and its role may have been underestimated [20].

In relapsed ovarian cancer tamoxifen can produce an overall response rate of approximately 11-13\% (range 0-56\%), and disease stabilization in about $30 \%$ of patients (range $21 \%$ to 41\%) [22-26]. Occasionally long-lasting cancer remission was observed. In the largest trial conducted by the Gynecologic Oncology Group (GOG) tamoxifen was used in 105 patients with stage III or IV ovarian cancer with persistent or recurrent disease after primary surgery and first-line $\mathrm{CHT}$ (some patients also received radiotherapy) [23]. The objective response rate of $17.1 \%$ including complete regression in $9.5 \%$ of patients was obtained. No cancer progression within 3 months in 50\% of patients was reported in 38\%. Clinical outcome for tamoxifen was not related to histological tumor type and patient's ER status. The reanalysis of the treatment results of 102 evaluable patients entered into this trial (95\% had previously received platinum-based therapy, none paclitaxel) confirmed a similar objective response among cisplatin-sensitive and cisplatin-resistant patients: $15 \%$ and $13 \%$, respectively [25]. For the whole group median PFS was 4.4 months (range 1.2-9.2 months).

The results of retrospective studies suggested that response rates for tamoxifen in less pretreated ovarian cancer patients seem better than those of heavily pretreated patients [20].

A combination of $\mathrm{CHT}$ and tamoxifen (as a CHT response modulator) in advanced ovarian cancer failing platinumbased $\mathrm{CHT}$ produced an overall response rate of $50 \%$ with a median duration of 8.5 months [27].

What is important, tamoxifen is safe and effective in cancer patients with renal dysfunction [26].

Disease stabilization was observed in half of patients treated for multiply recurrent epithelial ovarian cancer with fulvestrant; however, the median PFS was only 62 days [28].

Experimental data revealed that the SERMs (tamoxifen, raloxifene) can partially reverse multidrug resistance of ovarian cancer cells to anticancer drugs [29].

\section{Aromatase inhibitors (AIs)}

Aromatase inhibitors exert their effect through blocking aromatase - the enzyme complex that converts androgens to estrogens. This process, which is the major source of estrogen in postmenopausal women, is present in several normal 
Table 1. Selected phase II studies of hormonal therapy for ovarian cancer

\begin{tabular}{|c|c|c|c|c|c|c|c|}
\hline \multirow[t]{2}{*}{ Study } & \multirow{2}{*}{$\begin{array}{l}\text { Patients } \\
\text { (No.) }\end{array}$} & \multirow[t]{2}{*}{ Characteristics } & \multirow{2}{*}{$\begin{array}{c}\text { Number } \\
\text { of patients } \\
\text { with platinum- } \\
\text { sensitive tumor (\%) }\end{array}$} & \multirow[t]{2}{*}{ Treatment } & \multicolumn{3}{|c|}{ Treatment response } \\
\hline & & & & & $\begin{array}{l}\mathrm{RR} \\
(\%)\end{array}$ & PFS & OS \\
\hline $\begin{array}{l}\text { Ahlgren } \\
1993 \text { [22] }\end{array}$ & 29 & $\begin{array}{l}\text { Stage III or IV } \\
\text { refractory ovarian } \\
\text { cancer (cisplatin- } \\
\text {-based CHT in 86\%) }\end{array}$ & NR & $\begin{array}{l}\text { Tamoxifen } \\
40 \text { mg bid for } \\
30 \text { days, then } \\
20 \text { mg bid }\end{array}$ & 17 & - & - \\
\hline $\begin{array}{l}\text { Bowman } \\
2002 \text { [39] }\end{array}$ & $60^{a}$ & $\begin{array}{c}\text { Recurrence after } \\
\text { at least } 1 \mathrm{CHT} \\
\text { regimen }\end{array}$ & NR & $\begin{array}{l}\text { Letrozole } \\
2.5 \mathrm{mg} / \mathrm{d}\end{array}$ & $\begin{array}{l}\text { CR 0, PR 0, } \\
\text { SD 20, Ca125 } \\
\text { response } \\
(P R+S D) 35\end{array}$ & Med. 35 w & - \\
\hline $\begin{array}{l}\text { Hasan } \\
2005[48]\end{array}$ & 26 & $\begin{array}{l}\text { Recurrence (3 } \mathrm{CHT} \\
\text { regimens in } 50 \% \\
\text { of patients) }\end{array}$ & $9(35)$ & $\begin{array}{l}\text { Tamoxifen } 20 \text { mg } \\
\text { bid + Goserelin } \\
3.6 \text { mg/monthly }\end{array}$ & $\begin{array}{c}\text { 50; CR 3.8, } \\
\text { PR 7.7, SD 38.5 }\end{array}$ & Med. 4 mo. & $\begin{array}{c}\text { Med. } \\
13.6 \mathrm{mo} \text {. }\end{array}$ \\
\hline $\begin{array}{l}\text { Hatch } \\
1991[23]\end{array}$ & 105 & $\begin{array}{l}\text { Stage III or IV } \\
\text { persistent or } \\
\text { recurrent ovarian } \\
\text { cancer after } \\
\text { first-line } \\
\text { combination CHT } \\
\text { (platinum based } \\
\text { in } 92 \text { patients) }\end{array}$ & NR & $\begin{array}{l}\text { Tamoxifen } \\
20 \text { mg bid }\end{array}$ & $\begin{array}{l}\text { CR 9.5, med. } \\
7.5 \text { mo. } \\
\text { (max. } 17 \text { mo.) } \\
\text { PR 7.6, med. } 3 \text { mo. } \\
\text { (max. } 9 \text { mo.) } \\
\text { SD 38, med. } 3 \text { mo. } \\
\text { (max. } 8 \text { mo.) }\end{array}$ & - & - \\
\hline $\begin{array}{l}\text { Markman } \\
1996[25]\end{array}$ & 102 & $\begin{array}{c}\text { Stage III or IV, } \\
\text { with refractory } \\
\text { ovarian cancer after } \\
\text { first-line combination } \\
\text { CHT (platinum based } \\
\text { in } 97 \text { patients) }\end{array}$ & $20(21)$ & $\begin{array}{l}\text { Tamoxifen } \\
20 \text { mg bid }\end{array}$ & $\begin{array}{l}13 \text { (15 and } 13 \text { in } \\
\text { sensitive and } \\
\text { refractory } \\
\text { to platinum, } \\
\text { respectively) }\end{array}$ & Med. 4.4 mo. & - \\
\hline $\begin{array}{l}\text { Papadimitriou } \\
2004 \text { [36] }\end{array}$ & $27^{a}$ & $\begin{array}{c}\text { Recurrence after } \\
\text { at least } 1 \mathrm{CHT} \\
\text { (and tamoxifen } \\
\text { in 33\% of patients) }\end{array}$ & $18(67)$ & $\begin{array}{l}\text { Letrozole } \\
2.5 \mathrm{mg} / \mathrm{d}\end{array}$ & $\begin{array}{c}15 ; \\
\text { CR 5, PR 10, } \\
\text { SD } 19 \text { Ca125 } \\
\text { response (CR, PR } \\
\text { and SD in 4, } 11 \\
\text { and 18, } \\
\text { respectively) }\end{array}$ & 17-33+ mo. & - \\
\hline $\begin{array}{l}\text { Ramirez } \\
2008[41]\end{array}$ & $33^{a, b}$ & $\begin{array}{l}\text { Platinum- and } \\
\text { taxane-resistant } \\
\text { ER-positive } \\
\text { ovarian cancer }\end{array}$ & - & $\begin{array}{l}\text { Letrozole } \\
2.5 \mathrm{mg} / \mathrm{d}\end{array}$ & $\begin{array}{c}\text { PR 3, SD } 23 \\
\text { med. (PR+SD) } \\
9 w\end{array}$ & - & - \\
\hline $\begin{array}{l}\text { Smyth } \\
2007[40]\end{array}$ & $42^{a}$ & $\begin{array}{l}\text { Previously treated } \\
\text { ER-positive ovarian } \\
\text { cancer progressed } \\
\text { according to } \\
\text { Rustin's criteria }\end{array}$ & $23(52)$ & $\begin{array}{l}\text { Letrozole } \\
2.5 \mathrm{mg} / \mathrm{d}\end{array}$ & $\begin{array}{l}\text { PR 9, SD } 42 \\
\text { (med. } 12 \text { w) } \\
\text { Ca125 } \\
\text { response } 17\end{array}$ & $\begin{array}{c}\geq 6 \text { mo. in } 26 \% \\
\text { of patients }\end{array}$ & - \\
\hline
\end{tabular}

CHT - chemotherapy; NR - not reported; RR-response rate; $C R$ - complete response; $P R$ - partial response; $S D$ - stable disease; $P F S$ - progression-free survival; OS - overall survival; ER - estrogen receptor; Ca125 response - response using Rustin's Ca125 criteria; platinum-sensitive disease - recurred $>6$ months after cessation of platinum-based treatment

asome patients without objective response; $b 4$ patients with peritoneal cancer

tissues including peripheral adipose tissue, muscles, liver, and also in the tumor. Intratumoral estrogens derived from in situ aromatization may function as autocrine growth and mitogenic factors that prompt cancer cell proliferation independently of circulating estrogen. Estrogen synthesis in the tumor is decreased by blocking intratumoral aromatase. Aromatase expression, which might be useful for identifying the subgroup of patients who may respond to Al therapy, was found in 33-81\% of ovarian cancer tissues [30, 31]. Endometri- oid cancer tends to express higher levels of aromatase, which suggests that patients with that subtype more than those with other histotypes of ovarian cancer may benefit from $\mathrm{Al}$ therapy [30].

An inverse correlation between aromatase and ER $\alpha$ was reported [32]. The correlation of aromatase activity with PR in ovarian cancer was reported, but no significant differences in aromatase expression depending on tumor histotype, cancer cell differentiation and survival were found 
[30, 32-34]. The potential role of follicle-stimulating hormone (FSH), luteinizing hormone (LH) and other factors contributing to Al efficacy remains under investigation [7].

Data concerning potential predictive markers, useful for identifying those patients who have Al-sensitive tumors, have been studied, but the findings have been conflicting; in most studies there was no association between ER and PR and ovarian tumor response to Al therapy [7, 35, 36].

Preclinical studies demonstrated that exemestane enhanced the treatment effect of paclitaxel on aromatasepositive ovarian cancer cells, and pretreatment with formestane increased the sensitivity of human tumor cells to cellular cytotoxicity [37, 38].

Importantly, some data suggest that Als might be particularly useful for prolonging the intervals during which patients with recurrent ovarian tumor do not require platinum treatment; the longer the platinum-free interval, the more likely it is that the tumor will respond to platinum retreatment [7].

A stable disease rate of $19 \%$, and complete and partial response rates of $5 \%$ and $10 \%$, respectively, were achieved with letrozole treatment for relapsed epithelial ovarian cancer [36]. Others reported disease stabilization in $20 \%$ of patients, and Ca125 responses in 26\% [39]. Using Ca125 criteria, Ca125 stable/responding disease was linked to higher levels of $E R$, in particular $E R \alpha$, and epidermal growth factor receptor, and lower erbB2 [39, 40]. The use of letrozole in patients with recurrent platinum- and taxane-resistant ER-positive high-grade ovarian tumors resulted in achieving the median duration of clinical benefit (partial remission and stable disease in $3 \%$ and $23 \%$ of patients, respectively) of 9 weeks [41]. In this group of patients, no progression (doubling of Ca125) following 6 months on letrozole treatment was reported in $26 \%$ [40].

\section{Gonadotropin-releasing hormone (GnRH) analogues}

The GnRH analogues are synthetic gonadotropin agonists that act by binding with their receptors in the pituitary, resulting in a decline in both LH and FSH gonadotropin secretion. Subsequent reduction of gonadal steroids, which serve as tumor growth factors, causes reversible pharmacological castration. According to Polish authors, goserelin addition to postoperative CHT and RT may have a positive impact on survival in stage III and IV ovarian cancer patients [42]. In cases with chemo-refractory tumors, after two lines of therapy this hormonal agent produced partial remission in $17 \%$ and disease stabilization in $30 \%$ with respective median PFS of 8.5 and 5.3 months [43]. Others reported disease stabilization in 16\% of patients treated with triptorelin [44]. Lastly, in a prospective placebo-controlled study with advanced ovarian cancer patients, the addition of triptorelin to CHT had no impact on outcome [45]. No advantage of leuprorelin in platinum-refractory ovarian cancer was found in other studies [46, 47]. However, complete cancer remission lasting for over three years was observed occasionally, with GnRH agonist analogue therapy [47].

Similarly to other primaries, the concomitant administration of $\mathrm{GnRH}$ analogue and tamoxifen was explored
$[48,49]$. Complete estrogen deprivation in platinum refractory or recurrent ovarian cancer revealed cancer stabilization that lasted for at least 6 months in $50 \%$ of cases [48]. There were cases treated with goserelin and tamoxifen with no disease progression for over two years $[48,49]$. The use of goserelin and bicalutamide did not appear to prolong PFS in patients with epithelial ovarian cancer who were in the second or greater complete disease remission after $\mathrm{CHT}$ [50].

Opposite to CHT, endocrine therapy was well tolerated in the vast majority of patients. An additional benefit associated with endocrine therapy is its oral form and relatively low cost.

Unfortunately, endocrine therapy for ovarian cancer is not refunded in Poland. Current recommendations of the NCCC (National Comprehensive Cancer Network) classify endocrine therapy with anastrozole, letrozole, leuprorelin, medroxyprogesterone acetate and tamoxifen as a potentially active treatment option used in conjunction with $\mathrm{CHT}$ in recurrent disease [51].

In conclusions, the therapy of platinum-resistant and recurrent ovarian cancer has, in almost all cases, palliative intent. In this situation therapy tolerance and patient's quality of life are of main importance.

Endocrine therapy may be a palliative therapeutic alternative for selected ovarian cancer patients. This method might be considered particularly in patients with contraindications to $\mathrm{CHT}$ and those in whom we terminate cytotoxic treatment. With endocrine therapy disease stabilization was usually achieved. However, occasionally, this treatment produces longterm objective cancer remission. Research for prognostic factors associated with most benefits of endocrine therapy which may allow a better selection of patients for this therapy are justified. Moreover, the verification of endocrine therapy efficacy in well-designed trials is required.

\section{References}

1. Didkowska J, Wojciechowska U, Tarnowski W, Zatoński W. Nowotwory złośliwe w Polsce w 2009 roku. Centrum Onkologii - Instytut im. Marii Skłodowskiej-Curie, Warszawa 2011.

2. Gordon AN, Fleagle JT, Guthrie D, Parkin DE, Gore ME, Lacave AJ. Recurrent epithelial ovarian carcinoma: a randomized phase III study of pegylated liposomal doxorubicin versus topotecan. J Clin Oncol 2001; 19: 3312-22.

3. Gordon AN, Tonda M, Sun S, Rackoff W; Doxil Study 30-49 Investigators. Long-term survival advantage for women treated with pegylated liposomal doxorubicin compared with topotecan in a phase 3 randomized study of recurrent and refractory epithelial ovarian cancer. Gynecol Oncol 2004; 95: 1-8.

4. Parmar MK, Ledermann JA, Colombo N, et al. Paclitaxel plus platinumbased chemotherapy versus conventional platinum-based chemotherapy in women with relapsed ovarian cancer: the ICON4/AGO-OVAR2.2 trial. Lancet 2003; 361: 2099-106.

5. Pfisterer J, Plante M, Vergote I, et al. Gemcitabine plus carboplatin compared with carboplatin in patients with platinum-sensitive recurrent ovarian cancer: an intergroup trial of the AGO-OVAR, the NCIC CTG, and the EORTC GCG. J Clin Oncol 2006; 24: 4699-707.

6. Mutch DG, Orlando M, Goss T, et al. Randomized phase III trial of gemcitabine compared with pegylated liposomal doxorubicin in patients with platinum-resistant ovarian cancer. J Clin Oncol 2007; 25: 2811-8.

7. Li YF, Hu W, Fu SQ, Li JD, Liu JH, Kavanagh JJ. Aromatase inhibitors in ovarian cancer: is there a role? Int J Gynecol Cancer 2008; 18: 600-14. 
8. Zheng H, Kavanagh JJ, Hu W, Liao Q, Fu S. Hormonal therapy in ovarian cancer. Int J Gynecol Cancer 2007; 17: 325-38.

9. Zhou B, Sun Q, Cong R, et al. Hormone replacement therapy and ovarian cancer risk: a meta-analysis. Gynecol Oncol 2008; 108: 641-51.

10. Kommoss F, Pfisterer J, Thome M, Schäfer W, Sauerbrei W, Pfleidere A. Steroid receptors in ovarian carcinoma: immunohistochemical determination may lead to new aspects. Gynecol Oncol 1992; 47: 317-22.

11. Zhou R, Treeck O, Horn F, Ortmann O. Effects of prolonged tamox ifen treatment on receptor expression and apoptosis of ovarian can cer cells. Gynecol Oncol 2005; 96: 678-83.

12. Treeck O, Pfeiler G, Mitter D, Lattrich C, Piendl G, Ortmann O. Estrogen receptor\{beta\}1 exerts antitumoral effects on SK-OV-3 ovarian cancer cells. J Endocrinol 2007; 193: 421-33.

13. Arias-Pulido H, Smith HO, Joste NE, Bocklage T, Qualls CR, Chavez A Prossnitz ER, Verschraegen CF. Estrogen and progesterone receptor status and outcome in epithelial ovarian cancers and low malignant potential tumors. Gynecol Oncol 2009; 114: 480-5.

14. Cavalieri E, Frenkel K, Liehr JG, Rogan E, Roy D. Estrogens as endogenous agents-DNA adducts and mutations. J Natl Cancer Inst Monogr 2000; 27: 75-93.

15. Liehr JG. Is estradiol a genotoxic mutagenic carcinogen? Endocr Rev 2000; 21: 40-54.

16. Walker G, MacLeod K, Williams AR, Cameron DA, Smyth JF, Langdon SP. Estrogen-regulated gene expression predicts response to endocrine therapy in patients with ovarian cancer. Gynecol Oncol 2007; 106: 461-8.

17. Walker G, MacLeod K, Williams AR, Cameron DA, Smyth JF, Langdon SP. Insulin-like growth factor binding proteins IGFBP3, IGFBP4 and IGFBP5 predict endocrine responsiveness in patients with ovarian cancer. Clin Cancer Res 2007; 13: 1438-44.

18. Swerdlow AJ, Jones ME. Ovarian cancer risk in premenopausal and perimenopausal women treated with tamoxifen: a case-control study. Br J Cancer 2007; 96: 850-5.

19. Wright JW, Stouffer RL, Rodland KD. High-dose estrogen and clinical selective estrogen receptor modulators induce growth arrest, p21, and p53 in primate ovarian surface epithelial cells. J Clin Endocrino Metab 2005; 90: 3688-95.

20. Perez-Gracia JL, Carrasco EM. Tamoxifen therapy for ovarian cancer in the adjuvant and advanced settings: systematic review of the literature and implications for future research. Gynecol Oncol 2002; 84: 201-9.

21. Schwartz PE, Chambers JT, Kohorn El, Chambers SK, Weitzman H, Voynick IM, MacLusky N, Naftolin F. Tamoxifen in combination with cytotoxic chemotherapy in advanced epithelial ovarian cancer. A prospective randomized trial. Cancer 1989; 63: 1074-8.

22. Ahlgren JD, Ellison NM, Gottlieb RJ, et al. Hormonal palliation of chemoresistant ovarian cancer: three consecutive phase II trials of the Mid-Atlantic Oncology Program. J Clin Oncol 1993; 11: 1957-68.

23. Hatch KD, Beecham JB, Blessing JA, Creasman WT. Responsiveness of patients with advanced ovarian carcinoma to tamoxifen. A Gynecologic Oncology Group study of second-line therapy in 105 patients. Cancer 1991; 68: 269-71.

24. Karagol H, Saip P, Uygun K, Caloglu M, Eralp Y, Tas F, Aydiner A, Topuz E. The efficacy of tamoxifen in patients with advanced epithelial ovarian cancer. Med Oncol 2007; 24: 39-43.

25. Markman M, Iseminger KA, Hatch KD, Creasman WT, Barnes W, Dubeshter B. Tamoxifen in platinum-refractory ovarian cancer: a Gynecologic Oncology Group ancillary report. Gynecol Oncol 1996; 62: 4-6.

26. Sirisabya N, Li Y, Jaishuen A, Zheng HG, Gershenson DM, Kavanagh JJ. Tamoxifen is safe and effective in gynecological cancer patients with renal dysfunction. Int J Gynecol Cancer 2008; 18: 648-51.

27. Benedetti Panici P, Greggi S, Amoroso M, et al. A combination of platinum and tamoxifen in advanced ovarian cancer failling platinum based chemotherapy: results of a phase II study. Int J Gynecol Cancer 2001; 11: 438-44.

28. Argenta PA, Thomas SG, Judson PL, Downs LS Jr, Geller MA, Carson $\mathrm{LF}$, Jonson AL, Ghebre R. A phase II study of fulvestrant in the treatment of multiply-recurrent epithelial ovarian cancer. Gynecol Oncol 2009; 113: 205-9.

29. Perry WL $3^{\text {rd }}$, Shepard RL, Sampath J, et al. Human splicing factor SPF45 (RBM17) confers broad multidrug resistance to anticancer drug when overexpressed - a phenotype partially reversed by selective estrogen receptor modulators. Cancer Res 2005; 65: 6593-600.

30. Kühnel R, Delemarre JF, Rao BR, Stolk JG. Correlation of aromatase activity and steroid receptors in human ovarian carcinoma. Anticancer Res 1986; 6: 889-92.

31. Noguchi T, Kitawaki J, Tamura T, Kim T, Kanno H, Yamamoto T, Okada $\mathrm{H}$. Relationship between aromatase activity and steroid receptor levels in ovarian tumors from postmenopausal women. J Steroid Biochem Mol Biol 1993; 44: 657-60.

32. Cunat S, Rabenoelina F, Daurčs JP, Katsaros D, Sasano H, Miller WR, Maudelonde T, Pujol P. Aromatase expression in ovarian epithelial cancers. J Steroid Biochem Mol Biol 2005; 93: 15-24.

33. Kitawaki J, Noguchi T, Yamamoto T, Yokota K, Maeda K, Urabe M, Honjo H. Immunohistochemical localization of aromatase and its correlation with progesterone receptors in ovarian epithelial tumours. Anticancer Res 1996; 16: 91-97.

34. Slotman BJ, Kühnel R, Rao BR, Dijkhuizen GH, de Graaff J, Stolk JG. Importance of steroid receptors and aromatase activity in the prognosis of ovarian cancer: high tumor progesterone receptor levels correlate with longer survival. Gynecol Oncol 1989; 33: 76-81.

35. Langdon SP, Smyth JF. Hormone therapy for epithelial ovarian cancer. Curr Opin Oncol 2008; 20: 548-53.

36. Papadimitriou CA, Markaki S, Siapkaras J, et al. Hormonal therapy with letrozole for relapsed epithelial ovarian cancer. Long-term results of a phase II study. Oncology 2004; 66: 112-7.

37. Braun DP, Crist KA, Shaheen F, Staren ED, Andrews S, Parker J. Aromatase inhibitors increase the sensitivity of human tumor cells to monocyte-mediated, antibody-dependent cellular cytotoxicity. Am J Surg 2005; 190: 570-1.

38. Chen D, HackI W, Ortmann O, Treeck O. Effects of a combination of exemestane and paclitaxel on human tumor cells in vitro. Anticancer Drugs 2004; 15: 55-61.

39. Bowman A, Gabra H, Langdon SP, Lessells A, Stewart M, Young A, Smyth JF. Ca125 response is associated with estrogen receptor expression in a phase II trial of letrozole in ovarian cancer: identification of an endocrine-sensitive subgroup. Clin Cancer Res 2002; 8: 2233-9.

40. Smyth JF, Gourley C, Walker G, et al. Antiestrogen therapy is active in selected ovarian cancer: the use of letrozole in estrogen receptor-positive patients. Clin Cancer Res 2007; 13: 3617-22.

41. Ramirez PT, Schmeler KM, Milam MR, et al. Efficacy of letrozole in the treatment of recurrent platinum- and taxane-resistant high-grade cancer of the ovary or peritoneum. Gynecol Oncol 2008; 110: 56-9.

42. Rzepka-Górska I, Chudecka-Glaz A, Kosmider M, Malecha J. GnRH analogues as an adjuvant therapy for ovarian cancer patients. Int J Gynaecol Obstet 2003; 81: 199-205.

43. Sevelda P, Vavra N, Fitz R, Barrada M, Salzer H, Baur M, Dittrich C. Goserelin a GnRH-analogue as third-line therapy of refractory epithelial ovarian cancer. Int J Gynecol Cancer 1992; 2: 160-162.

44. Duffaud F, van der Burg ME, Namer M, et al. D-TRP-6 LHRH (Triptorelin) is not effective in ovarian carcinoma: an EORTC study. Anticancer Drugs 2001; 12: 159-62.

45. Emons G, Ortmann O, Teichert HM, et al. Luteinizing hormone-releasing hormone agonist triptorelin in combination with cytotoxic chemotherapy in patients with advanced ovarian carcinoma. A prospective double blind randomized trial. Decapeptyl Ovarian Cancer Study Group. Cancer 1996; 78: 1452-60.

46. duBois A, Meier W, Lück HJ, et al. Chemotherapy versus hormonal treatment in platinum- and paclitaxel-refractory ovarian cancer: a randomized trial of the Germans Arbeitsgemeinschaft Gynaekologische Onkologie (AGO) Study Group Ovarian Cancer. Ann Oncol 2002; 13: 251-7.

47. Paskeviciute L, Roed H, Engelholm S. No rules without exception: long term complete remission observed in a study using a $\mathrm{LH}-\mathrm{RH}$ agonist in platinum-refractory ovarian cancer. Gynecol Oncol 2002; 86: 297-301.

48. Hasan J, Ton N, Mullamitha S, Clamp A, McNeilly A, Marshall E, Jayson GC. Phase II trial of tamoxifen and goserelin in recurrent epithelial ovarian cancer. Br J Cancer 2005; 93: 647-51.

49. Hofstra LS, Mourits MJ, de Vries EG, Mulder NH, Willemse PH. Combined treatment with goserelin and tamoxifen in patients with advanced chemotherapy resistant ovarian cancer. Anticancer Res 1999: 19: 3627-30 
50. Levine D, Park K, Juretzka M, et al. A phase II evaluation of goserelin and bicalutamide with ovarian cancer in second or higher complete clinical disease remission. Cancer 2007; 110: 2448-56.

51. National Comprehensive Cancer Network (NCCN) v. 3. 2012.

\section{Address for correspondence}

dr hab. n. med. Krystyna Serkies

Klinika Onkologii i Radioterapii

Gdański Uniwersytet Medyczny

Dębinki 7

80-211 Gdańsk, Poland

tel. +48583492248

e-mail: kserkies@wp.pl

Submitted: $\quad 5.10 .2009$

Accepted: $\quad 4.11 .2011$ 